\title{
Strengthening Supply Chain for Growth of Organized Retail Industry
}

\author{
Mandavi Sahu \\ Assistant Professor Institute of Management, Pt. Ravi Shankar Shukla University, Raipur
}

\begin{abstract}
The continuing growth and expansion of organised retail Industry in India has opened the door for new investment opportunities as well as to make India strongest economy in the world. Effective supply chain management is the key driver for the success of organised retail industry. Retail Industry had emerged as one of the most dynamic, versatile and fast paced change industries due to entering of many new player (MNCs) in the market. Recent researches have shown that the growth rate of organised retail sector was $42 \%$ in 2008 and now in 2015, it is forecast to be around US\$ 600 billion, and thereby registering a CAGR of 24\% in organised retail, since 2020. Which lead to a great expansion and scope of organised retail in India? This paper study how supply chain management strengthening the organised retail market and how to create a strong economy and facing a major challenges in Indian market in context to infrastructure, supply chain management.
\end{abstract}

Keyword: $M N C$, Challenges, compound annual growth rate.

\section{Introduction}

The retail industry in Indian has emerged as one of the most dynamic and fast-paced industries, driven by robust economic growth, rapid urbanisation and changing lifestyles, increasing incomes, and aspirations of the Indian retail consumer. Supply chain plays an important role in retail growth which involves management of man, material, mechanism, markets and money. Supply chain management involves the integration of activities that flow from internally within companies and reach to external market suppliers. The goal of retail supply chain management system is to reduce inventory cost, proper delivery of goods, resource management and customer satisfaction. Hence, an effective retail supply chain management generate efficiency, effectiveness, high productivity and maintain flow of information between intermediaries.

\section{Organised Retail Sector In India}

Indian market is divided into two major sector,1) organised retail and 2) unorganised retail sector. The major portion of Indian market is covered by unorganised retail which is run by, mom and pop stores, traditional stores and family owned business. They are facing problem due to lack of fund, modern infrastructure, warehouse facility, assortments, and improper transportation of goods delivery. In today scenario a very competitive market is prevailing, and the expectation of the customer is also increased, regarding variety of assortments, services, merchandising facilities, keeping warehouse facilities providing product at any time at anywhere. Which shows huge scope of organised retail in India? The IBEF (Indian Brand Equity Foundation) study report has indicated about huge scope of organised retail in future. The organised retail, which was comprised of $7 \%$ of the whole organised retail market in 2011-12, is estimated would grow at a CAGR of $24 \%$ and will attain $10.2 \%$ of the total organised retail sector by 2016-17.

Manufacturer and whole seller are informed by their retailer with regard to sales forecast, delivery delay, customer complaint, defective items, inventory turnover. From these information the manufacture modifies the product.

The growth of organised retail market depends upon the following factors.

- Increase the value addition of product and service

- Holding inventory.

- Warehouse facility.

- Providing variety of assortment

- Proper infrastructure.

- Maintain the demand and supply chain of products.

Indian retailers deal with fresh fruit and vegetables. This show the supply chain process is fragmented in different group and every group perform different role of supply chain management, it is diversified for big retailers and small grocery stores. For effective supply chain management the manufacturer should more focus on logistic management, should be more concern about operation system and technology, so that delivery of goods should at right time, right place and to right persons. 


\section{Role of Retail Supply Chain Management}

Supply chain management is the key driver which runs the retail business successfully; it supports to supplying goods from manufacturers, to whole sellers, through retailers and then reach to ultimate consumers. Earlier, India was facing tough situation for supply of goods from manufacturer to retailers largely due to poor transport facilities, poor roads and lack of warehouses. Therefore, it was very difficult to sending products from supplier to small retailers, shopkeepers and vendors. The poor supply chain is having direct impacts on manufacturers, retailers and even customers. Which ultimately create market and economic problems like unavailability of goods, increased market prices, higher inflation rates, and black marketing? Thus, the effective supply chain management can play effective role in fulfilling the following objectives:

- Ensure proper delivery of goods like reaching products at right time, at right place and to the right customer

- Proper information flow among retail supply chain stakeholders including customer feedback will ensure uninterrupted supply of quality products.

- Effective procurement, warehouse storage, inventory management to avoid shortage at any stage of supply chain.

Effective retail supply chain system ensures for fast and prompt of delivery of goods, in right condition, at right place, and at right time. This enable the retailer to service the customers and increase their customer base as well as retaining old and existing customers. Thus, the retail supply chain management play a significant role in organised retailing and become back bone of the entire functioning of the retail shop. Therefore, for the expansion and exploration of organised retails markets in India, it is very important that retailer should come with innovative strategies and re-evaluate their supply chain system to maintain the pace of retail growth. The detailed supply chain process circle has been summarized in figure 1 .

Figure 1: Retail supply chain process circle

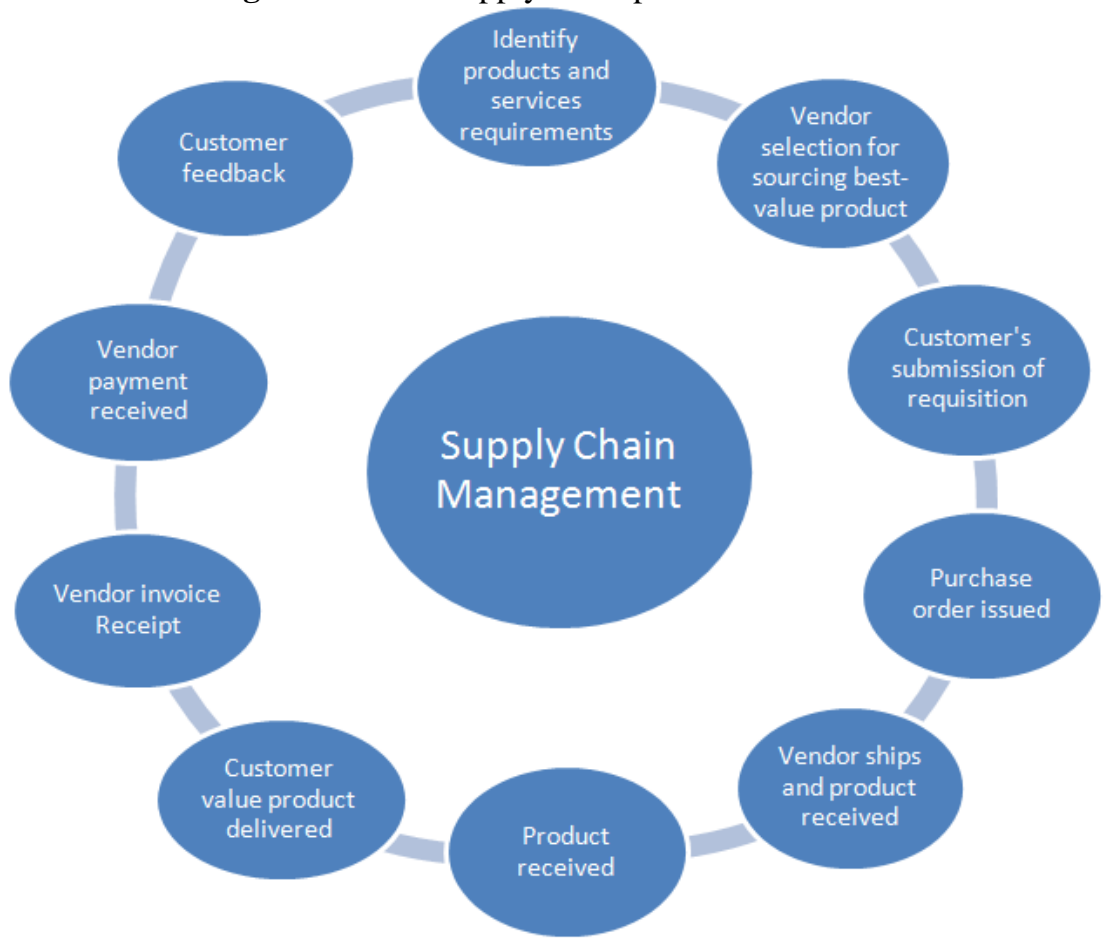

Each stages consist of a complete process from product manufacturing and it is important for supply chain management process, every firm following the stages of supply chain management process after this product will reach retailers and then to ultimate consumers. Organised retailer follow the supply chain cycle and full fill the expectation of desired product. The problem comes on unorganised traditional retailers and small shopkeeper, due to lack of information and awareness, they do not know how to maintain the demand and supply of product by effectively follow supply chain process. this is one of the reason, still the organised retail strategy is not reach to rural India, for this it require the support of Indian government to take necessary steps for expansion of organised retail in India as well as the proper information related supply chain process should be provide the small retailers, warehouse facilities as well as a better transport system is required so the product reach to different parts of the country, without any hindrance. 


\section{Literature Review}

Retail supply chain management is a continuous evolving field which practises on two different field of management, first is supply chain Management and second is retailing perform by scm by the help of this literature review, we understand different author gives their opinion for effective supply chain and logistic management of organised retail, and identify the problem ,how the better supply chain will make. And to identify the best practises should be adopted by logistic management food product dealing retailer and grocery out let, Leigh Sparks (2006)3 focus on detailed account of the evolution of retail Supply chain management from there paper. He discussed a number of changes are take places in modern organised retail supply chain which is directly proportional to changing demands of consumers. He also describe how these changes gives a number of Implications for systematic management of retail supply chains system. The logistics is an important component of modern supply chain Management give more emphasis. Logistics should be maintain properly by internal to the retail Outlets.

Kotzab (2005)34 gives more importance to logistics in side the outlet and out side the store) an outlet. Seyed-Mahmoud Aghazadeh (2004),35 gives different approaches for exploring the ways of improving logistics and distribution supply chains of specially food retail. The paper also explains the different concepts of logistics and supply chain well.

The study by Bourlakis, Michael and Bourlakis, Constantine (2006)32 they emphasis on the integration process of retailer's information technology strategy With logistics management and to show the impact on retailer's distribution and operation management performance that can be highly influenced by these integration . Leigh Sparks, find " according to times the changes comes in customer demands, supply chain process and logistic in and out service, and depend upon the changing scenario" Retail Biz, June 2006, pp 2123. 34 Herbert Kotzab, Frederiksberg and Christopher Teller (2005), "Development and Empirical Test of a grocery retail in store logistics model, British Food Journal, Vol. 107 No. 8, pp. 594-605. 35 Seyed-Mahmoud Aghazadeh (2004), they focus on "Improving logistics operations across the food industry supply chain", International Journal of Contemporary Hospitality Management. Volume 16 No. 4, pp 263-268.

The study discuss the major impact of supply chain management on customer behaviour and the distribution system, and discuss the major success and failure of retail industry, different author present different views and opinion on supply chain which is, based on time and customer demand . From the study we find there should be major modification and change should be required for effective supply chain and logistics management for the success of an organised retail industry.

\section{The major objective of this study}

- To find out the major challenges faced by the organised retailers in supply chain management,

- How to remove these challenges for generate effectiveness in $\mathrm{scm}$.

- To focus on major factors which strengthen the supply chain management of organised retail sectors?

- To find out the major key attributes from the past research and the major gap factor comes in the path of generating the effectiveness of good supply chain.

\section{Challenges faced by retailers}

- For keeping and maintain inventories is another major challenges faced by small retailers. Providing goods at any time to customers they required good won and warehouse facilities which are not possible, due to shortage of funds.

- Poor road, network facilities and unavailability of transport medium, becomes a major challenge for manufacturers to reach remote areas. In India 75\% people living in villages and depends upon the small general retailers for buying goods, these retailer facing problem because of unavailability of transport medium.

- Lack of information, awareness and improper supply chain, the small rural retailer does not replace the product from their stores time to time which causes expiry and spoiling of products, and keeping this products in store cause a unhygienic and health affected issues for villager.

- The industries and manufacturers facing challenges because of improper planning of logistics and operation managements that lead to ineffective distribution system of supplying goods.

- The major challenges faced by small retailers, manufacturers whole sellers is to make proper infrastructure with pleasant ambience for attracting more and more customers because shortage of resources, which is not possible.

\section{Factors which can strengthen the retail supply chain}

- Top management commitment: it is very important the top management should be committed towards there there goals. The goal should company's objective as well as welfare of society.

- Development of effective scm strategy. which leads proper supply chain process planning of goods after manufacturing the firm should know there responsibility 
Towards retailer and whole seller.

- Devoted resources for supply chain the company should maintain the resources like information, manpower, material, capital and establish proper communication.

- Use of modern technologies, now every firm is update, and uses new technologies for updating there resources and improving the work culture.

- Information sharing with supply chain member, proper communication should establish among the channel member so that the product react the destination place on time.

- Forecasting of demand on sale, by maintain a proper supply chain process the demand and supply should be maintained as well as the retailer also give the information about how product is required, (forecasting the demand of sale) and

* Trust development with supply chain partner is to make a brand image between supply chain and small retailers.

* Supply chain management has to improve so it develop its just $\mathrm{n}$ time capabilities in system

* Manufacturing firm should develop a better relationship with their reliable supplier.

- Firm manufacturing process should be flexible in nature, it gives more benefits in terms of cost as well as renew their resources.

* The firm should focus on the core strength, rather diversified they should focus on core manufacturing process, it creates optimum utilisation of resources of core area, more specification as well as qualitative products.

* Every firm have a long term mission, vision, for achieve these goal They should have strong strategic policy, plan. These are the factor for strengthens the supply chain management in India

\section{Conclusion}

Earlier the scope of organised retail in India is very limited. Due to globalization, and entering of foreign player(MNC) in India there is huge prospect of organised retail in India ,it will be possible, by strengthen the supply chain system, for this the government, should take necessary initiative by providing the better transport facility, infrastructure, warehouse facilities, giving funds for new retailers, provide information and creating awareness how to establish an organised retail which help to create a strong economy. The problem of unemployment can be removes by increasing the expansion of organised retail sector in India. It is an integrated process where every activity of supply chain should inter linked with logistic management can be operated with the help of information technology, throughout the cycle time of each step of the process so that timely action can be taken.and form effective Supply chain process which helps manufacturers, for cost benefits, time saving, effective logistic management, increases profit margin and customer satisfaction.

\section{Reference}

[1]. Ravinder Kumar, Rajesh K. Singh, Ravi Shankar, 'Critical success factors for implementation of supply chain management in Indian small and medium enterprises and their impact on performance, IIMB Management Review (2015) 27, 92e104

[2]. Piyush Kumar Sinha, and Sanjay Kumar Kar, "An Insight into the Growth of New Retail Formats in India" Research and Publications, IIMA, W.P. No.2007-03-04

[3]. K. Ratna Manikyam "Organized Retailing In India - Challenges and Opportunities" Asia Pacific Journal of Marketing \& Management Review Vol.1 No. 2, October 2012, ISSN 2319-2836

[4]. B. Kusuma, N.Durga Prasad, M. Srinivasa Rao "A Study on Organized Retailing and Its Challenges and Retail Customer Services", Innovative Journal Of Business And Management, ISSN: 22774947.

[5]. Kanwaljeet "Organised Retailing in India: Opportunities and Challenges" IRACST - International Journal of Commerce, Business and Management (IJCBM), ISSN: 2319-2828 Vol. 4, No.2, April 2015 p.p 1117- 1118.

[6]. http://www.ibef.org/industry/retail-india.aspx

[7]. http://info.shine.com/industry/retail/7.html

[8]. http://www.ibef.org/industry/indian-retail-industry-analysis-presentation

[9]. https://www.kpmg.com/IN/en/IssuesAndInsights/ArticlesPublications/Documents/BBG-Retail.pdf

[10]. http://business.mapsofindia.com/india-retail-industry/role-of-supply-chain-in-indian-organized-retail.html

[11]. http://www.slideshare.net/pxkohli/retail-supply-chain 